\author{
T. Momot, O. Filonych, A. KosiaK, O. LOBACH
}

\title{
BALANCED SCORECARD OF SAFETY-ORIENTED MANAGEMENT FOR THE CONSTRUCTION INDUSTRY ENTERPRISES
}

The article is devoted to the study of the theoretical and methodological foundations for the development of a balanced scorecard for ensuring safe-oriented management of enterprises in the construction industry. The subject of the research is a set of theoretical, methodological and practical aspects to ensure the formation of the balanced scorecard development to ensure safe-oriented management of enterprises in the construction industry. The purpose of the article is to develop theoretical and methodological provisions and substantiate practical recommendations for the formation of a model of a balanced scorecard for ensuring safe-oriented management of enterprises in the construction industry, taking into account the interests of all groups of stakeholders. Objectives of the work: to analyze modern trends in the development of enterprises in the construction industry in Ukraine; to generalize approaches to the definition of the concept of safety-oriented management; explore and organize the elements of safety-oriented management; to develop a model of a balanced scorecard for ensuring safe-oriented management in the corporate security system of enterprises in the construction industry. In the course of the study, the following methods were used: abstract-logical analysis, theoretical generalization and systematization, system analysis. The paper analyzes the dynamics of the development of enterprises in the construction industry in Ukraine in the context of the introduction of quarantine measures related to COVID-19. Factors constraining construction activities have been identified, which include financial constraints, insufficient demand, labor shortage, and weather conditions. Approaches to the definition of security-oriented management have been generalized and the definition of security-oriented management in the corporate security system has been improved. The elements of safety-oriented management are systematized with the specification of such components as risk assessment, development and implementation of security policy, definition of requirements, establishment of control and monitoring of the external and internal environment. A model of a balanced scorecard for ensuring safe-oriented management of enterprises in the construction industry has been developed. Conclusions. In the course of the study, the expediency of forming a balanced system of indicators for ensuring safe-oriented management of enterprises in the construction industry was substantiated, taking into account the dynamics of the performance of construction work during 2019-2021. The elements of the system of safe-oriented management are presented in detail and the expediency of the formation of a balanced system of indicators for ensuring the safe-oriented management of enterprises in the construction industry is substantiated. The sequence of the formation of a balanced scorecard for ensuring safety-oriented management is detailed with the specification of a scorecard for assessing strategic goals for the components of a balanced scorecard: finance, customers, internal business processes, training and development.

Keywords: safety-oriented management; corporate security; balanced scorecard; construction industry enterprises.

\section{Introduction}

With the introduction of quarantine measures related to COVID-19, the dynamics of changes in processes and phenomena increases the priority of safety issues in the construction industry. Thus, according to the State Statistics Service of Ukraine in 2020, the contribution of the construction industry to GDP is likely to increase to $2.9 \%$ compared to $2.7 \%$ in 2019. For comparison, this figure in Slovakia is $7.9 \%$, Poland $-7.7 \%$, Sweden $6.8 \%$, Romania - $6.1 \%$ [1]. Thus, the construction industry of Ukraine has significant growth potential and needs to attract additional investment resources.

The construction industry is always sensitive to the deteriorating economic situation in the country. Thus, the volume of construction work performed in 2020 increased by $4 \%$ compared to 2019 , which is due only to the growth in infrastructure immediately by $14.8 \%$ to UAH 120.6 billion. and moderate dynamics in non-residential construction. The segment of housing construction according to the data of 2020 showed a drop of $18.5 \%$ at once - to UAH 28.4 billion. A clear trend of growth in the construction of infrastructure projects is associated with the introduction in March 2020 of the program "Large Construction" (fig. 1). According to the estimates of the Ukraine Economic Outlook Group, the impact of investments in "Large Construction" in the amount of UAH 136 billion. in UAH 156 billion. indirect growth of other industries and UAH 120 billion. GDP in construction. In total, if this program falls out of domestic demand, the fall in real GDP in 2020 could reach 8-9\% against the projected minus 5\% [2].

According to the State Statistics Service, indicator of business confidence in construction, which is one of the components of the Economic Sentiment Indicator (ESI) in Ukraine (fig. 2), significantly deteriorated in the second quarter of 2020 (from $-10.6 \%$ in the first quarter of 2019 to $-48.2 \%$ ) and remains low in the first quarter of 2021 (at $-29.2 \%)$.

Among the factors constraining construction activity according to the results of the survey of construction companies are the following: financial constraints, insufficient demand, labor shortages, weather conditions [3].

In such conditions, the complexity of business processes in construction, associated with the implementation of a range of works for the successful and timely completion and commissioning of facilities, ensuring effective interaction and meeting the requirements of all stakeholders (developers, investors, contractors, supervisors). and regulators and others) determines the search for new safety-oriented management tools for a detailed analysis of the environment in which enterprises operate in the industry, in order to integrate the risk management system into the management system of enterprises in the construction industry. 


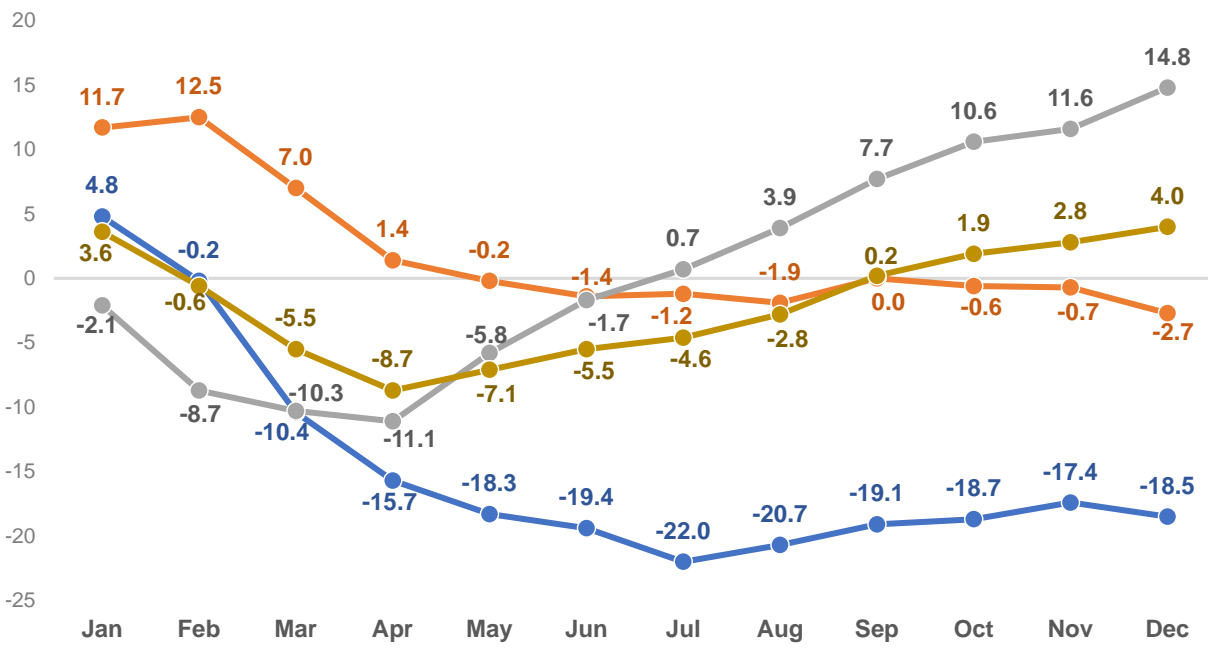

Fig. 1. Dynamics of construction production indices in $2020, \%$ (cumulative total for the corresponding period of the previous year)

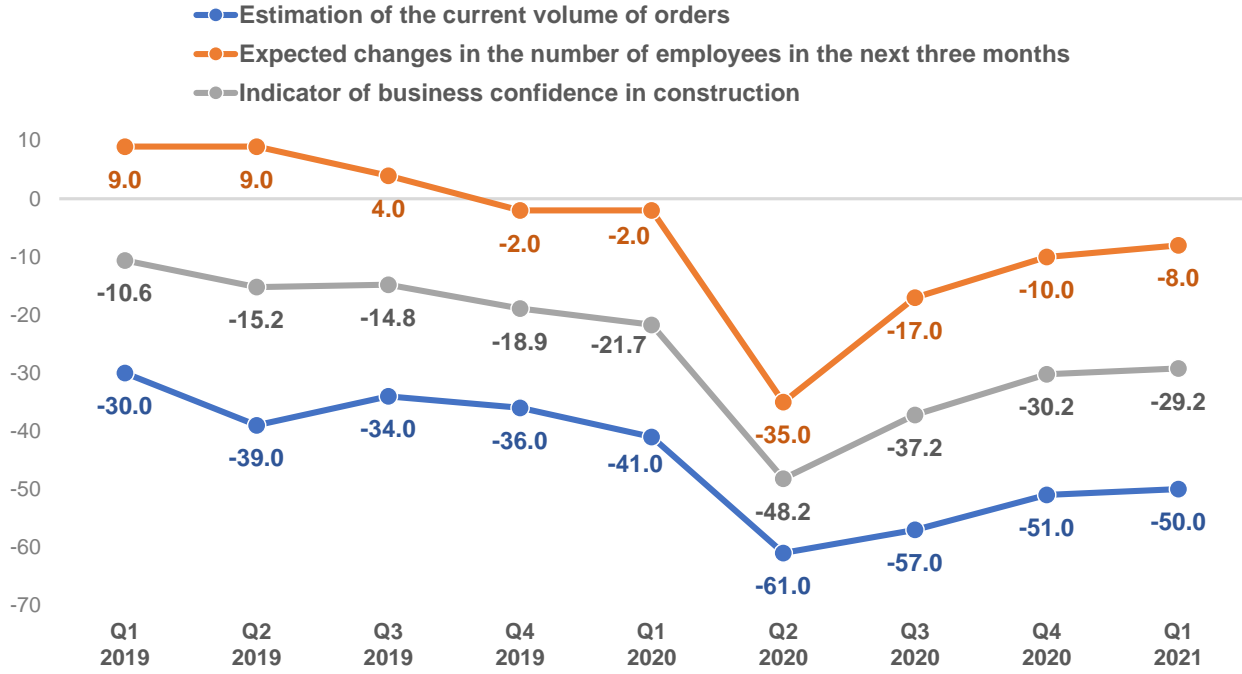

Fig. 2. Dynamics of indicators of business confidence in construction in 2019-2021, \%

\section{Analysis of recent research and publications}

The problems of ensuring safe-oriented management are considered in the works of domestic scientists, such as I. A. Bashinskaya, L. A. Voloshchuk, N. I. Gavlovskaya, O. B. Zachko, V. A. Omelyanenko, I. P. Otenko, A. V. Prokopenko, L. A. Ptashchenko, E. N. Rudnichenko. Analysis of approaches to defining the concept of safety-oriented management in the research of domestic scientists shows their focus on solving problems within the existing management functions, in particular the development of methodological basis for safety-oriented management projects of complex organizational and technical systems [4]; formation of a driver for the implementation of safety-oriented management of foreign economic activity of enterprises, as a managerial innovation and formalization of the process of its implementation. [5]; development of theoretical and methodological basis and methodological provisions and recommendations for safety-oriented management by innovative development of domestic industrial enterprises [6], substantiation of the main aspects of the conceptual basis of the mechanism of safety-oriented management of industrial enterprises [7] and safety-oriented anti-raiding [8].

Thus, according to the definition of I. A. Bashinsky, safety-oriented management is defined as management aimed, on the one hand, at minimizing the negative impact of risks, and on the other hand, at maximizing the benefit of probabilistic opportunities to obtain them. At the same time, the formation and functioning of the safety-oriented management system should be based on such principles:

- the principle of compliance (all safety-oriented measures must be legal within the legal field and must comply with the current strategy of the enterprise);

- the principle of systematization (safety orientation should be carried out on the basis of comprehensive consideration of factors, potential threats and probable risks, taking into account all elements of the system in their entirety, integrity and unity);

- the principle of continuity (security-oriented management occurs on an ongoing basis, which involves monitoring the development of events related to threats at all stages of management, including monitoring and control); 
- the principle of timeliness with priority of preventive measures (this creates the maximum possible objectivity of decisions on threats, based on complete information, dynamics and assessment of the prospects of the environment of the enterprise);

- the principle of economic feasibility (it is necessary to justify safety-oriented measures when comparing the profitability and financial capabilities of the enterprise, which should exceed the level of risk of operations);

- the principle of interaction and coordination of all divisions of the enterprise with a clear differentiation of areas of responsibility and integration into the procedures of identification and evaluation of all divisions of the company and selected external partners, as well as their management;

- the principle of extending assessment and management to all hazards, even those that are outside the scope of financial and insured risks and cannot be quantified at this level of development [7].

Prokopenko A.V. and Omelyanenko V.A. also pay attention to the expediency of taking into account the principle of controllability [9]. At the same time, the authors note that taking into account the principle of manageability by safe-oriented management, in order to solve the problem of its integration into the system of management of the functioning and development of the enterprise, the theoretical basis of its research and management is the system approach, which makes it necessary to coordinate the functions of the strategic development management system with the functions of safety-oriented management, namely: evaluation and analytical, presented by analysis and evaluation, diagnosis, monitoring; planning and forecasting, which ensures the development of plans and programs; organizational which is defined by integration, coordination, coordination, support, realization, control; motivational orientation of staff on development and training, ensures its readiness to implement innovative changes.

Summarizing, it can be argued that safety-oriented management is one of the functions of corporate governance, which at an early stage allows to identify and effectively withstand events that may pose a threat to financial sustainability and the continued functioning of the enterprise.

The main elements of safety-oriented management are detailed in $[5,10,11,12,13,14,15]$. As a type of management activity, safety-oriented management provides for the presence of an object and a subject of management.

Enterprise safety-oriented management objects are enterprise corporate security, accordingly, management decisions are made within such object to optimize business processes and the profitability of using enterprise resources, as well as to current and potential risks and threats to enterprise activity.

The subjects of safety-oriented management of the enterprise are its management, security personnel and all personnel.

The content of safety-oriented management is to recognize corporate security as a priority for the operation of the enterprise in the face of the negative impact of the environment. At the same time, it is important to ensure the profitable activity of the enterprise.

As noted by Voloshchuk L.O. according to economic tools safety-oriented management is mainly preventiveindicative, where indicative methods are used mostly in the development process, and preventive and anticipative at the peak of development, when traditional indicators of economic growth will show a high level of economic security, but at the same time signal the potential new threats to innovative development [6].

The mechanism of safety-oriented management is considered as a set of managerial, economic, organizational, legal and motivational ways to harmonize the interests of the enterprise with the interests of the environment, which, taking into account the peculiarities of the enterprise, provides a profit sufficient to ensure corporate security.

It should be noted that safety-oriented management plays many key roles in the organization of the management system, including risk management, crisis management, information security, crime detection, fraud prevention, physical security, investigation and business continuity planning.

In this context, the strategy of safety-oriented management should include strategies, mechanisms (coordination, training, regulation, conservation and protection), organizational methods, forms of strategic management of economic security, as well as methods of selection and coordination of adaptive measures that meet development guidelines. enterprises. At the same time, the classification of security-oriented development strategies determines passive and active types of strategies: passive survival, which use the available opportunities and are a typical way of action for the enterprise in a stable and predictable environment; active survival, aimed at active search and effective use of market opportunities; active impact on the environment, including actions to actively seek and create new opportunities for enterprise development through innovation, strategic competencies and knowledge [14].

To implement safety-oriented management, it is important to fulfill a group of conditions. So, in the first group of conditions, Pritis V.I. refers to the conditions that depend on the actions and decisions of the management of the enterprise, that is, at the micro level you can influence their creation and development. These conditions include: flexibility of the management system; responsiveness to negative impacts; the presence of a specialized economic security unit or individuals responsible; Defining the functional responsibilities of those responsible and clearly assigning authority; Adequate resources; a system of motivation of employees has been formed; internal control system is established in the context of the main processes and functional activities; development of the marketing component (analysis of potential markets, product promotion, other means of combating competitors); Interaction with local authorities has been established; interaction with mass media and public organizations [15].

The second group of conditions for the implementation of safety-oriented management includes 
those on which the enterprise has no direct influence and is forced to perceive them in accordance with existing realities, forming adaptation mechanisms: the stability of the monetary unit in a certain range (at least within a year); stability of legislation; availability and stability of standards and product quality certification system; the possibility of sailing to form a strategy for the development of territories; the existence of regional policies for the development of both selected industries and individual enterprises; the possibility of sailing to form a strategy for the development of the industry [15].

Summing up, it is worth defining "safety-oriented management" as a type of management activity, a set of coordinated actions, measures and processes aimed at achieving the optimal level of corporate security in the process of enterprise development, the key task of which is to balance between the level of corporate security and the effectiveness of enterprise development, which leads to the formation of a balanced information and analytical support system of safety-oriented management taking into account the interests of all groups of stakeholders.

Goals and objectives of the study. The purpose of the article is to develop theoretical and methodological provisions and substantiate practical recommendations on the formation of a model of a balanced scorecard for ensuring safety-oriented management of construction industry enterprises, taking into account the interests of all stakeholder groups.

\section{Study materials and methods}

The theoretical and methodological basis of the study were the scientific works of leading economists, analytical materials of the State Statistics Service of Ukraine. The study used such methods as: abstract-logical analysis, dialectical, theoretical generalization, system and statistical analysis, cognitive modeling, system and statistical analysis, graphical method.

\section{Study results and their discussion}

Important components of the safety-oriented management system are risk assessment, development and implementation of safety policy, definition of requirements, establishment of control and monitoring of the external and internal environment. Risk assessment is performed in order to inform the top management about the potential impact on corporate security of various risks and threats that may be due to internal or external changes in the environment. Internal changes in the environment occur due to changes in goals, acquisition of new resources and changes in the management system, and so on. External changes are due to the emergence of new threats, the introduction of new laws, directives of government bodies that have jurisdiction over the organization, or the discovery of new opportunities in risk control.

The development and implementation of security policy involves the definition of restrictions on the behavior of components of the internal system, as well as those that may be imposed on the actions of potential attackers. Based on the results of the evaluation, the existing policies, guidelines and procedures are regularly reviewed in order to update or create new ones in the absence of any. Updated or newly created policies should be reviewed interactively to fill gaps, resolve inconsistencies, and eliminate duplication. When approving, new or updated security policies should be consistent with organizational objectives. The process should involve all stakeholders of the enterprise, including management, departments involved and security professionals.

Based on the developed policies, a set of requirements for the security system is developed. These are the procedures and methods at the levels of hierarchy that are necessary to protect personnel, infrastructure and resources. Requirements should be organized in a hierarchical structure, from the highest level to the breakdown into details. The depth and breadth of requirements depends on the size of the enterprise and its mission. At the highest level of the hierarchy, the desired levels of protection of physical resources, non-physical assets and personnel are determined. Requirements specifications should take into account best security practices, specific practices in the market segment of the enterprise, laws and regulations and the unique socio-technical environment of the enterprise itself. Once defined, requirements should be agreed with a set of defined protocols and policies and revised if necessary.

Monitoring is carried out to prevent, detect and correct harmful and undesirable events. Requirements are implemented by new or modification of existing controls. If new controls are needed, then alternatives should be evaluated and a choice made.

Monitoring of the external and internal environment is considered as a stable stage of ensuring the protection of the enterprise through control procedures. With regard to the internal environment, adverse events are monitored, compliance with policies, protocols, requirements and the identification of new vulnerabilities. Violations of compliance are brought to the attention of stakeholders and recommendations are given on the application of appropriate actions. An unforeseen event will require updating the security database and initiating a risk assessment. Similarly, the external environment is monitored to identify new threats and new means of control. Environmental change goes through the same process to further modify controls, requirements and policies.

The application of these procedures within the process of organizing safety-oriented management is carried out on the basis of information and analytical support. Given that the level of corporate security of construction companies is important not only for internal stakeholders such as shareholders, managers, staff, but also for external ones such as the state (bankruptcy of large construction companies leaves the country GDP growth, leads to the need to resolve conflicts between developers and customers, requires financial resources to solve problems), competitors (identify market segments in 
which competition takes place, determine its nature, identify general trends in the competitive environment, analyze the activities of competitors and the impact of their activities on the enterprise itself), suppliers is important in terms of the ability to pay for goods, services or credit resources, the ability to further receive income from joint activities), customers (safety of the enterprise is a prerequisite for the fulfillment of its obligations to the customer, ensuring the agreed quality those works, project deadlines, are a prerequisite for customer confidence in the company, and as a consequence of the volume of orders and, accordingly, the volume of profits), as information and analytical support safety-oriented management it is advisable to use a balanced scorecard taking into account the interests of all stakeholder groups..

The development of a balanced scorecard of safetyoriented management is a long-term process that covers all areas of construction companies, including financial indicators as one of the main criteria for assessing the results of the enterprise, and non-financial indicators that assess customer and shareholder satisfaction, internal business efficiency -processes, the potential of employees to ensure long-term financial success of the enterprise. The balanced scorecard essentially transforms the mission and overall management strategy of the company into a system of interrelated indicators that are more

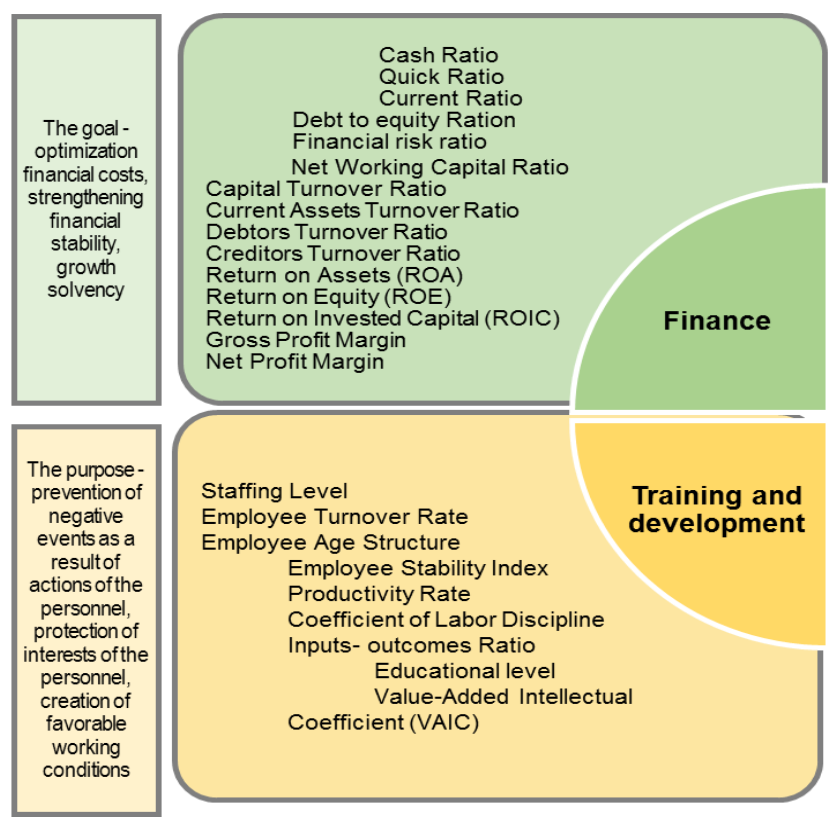

understandable to ordinary staff and controlled by different departments of the company.

The development of a system of balanced scores always begins with the definition of the overall mission or overall strategy of the enterprise. The main strategic goal of a balanced scorecard of safety-oriented management is to ensure a sufficient level of corporate security in the process and as a result of company development in order to maximize profits, ensure the interests of all stakeholder groups, safe implementation of business projects. Taking into account the above, at the first stage for each area of a balanced scorecard, including finance, customers, training and staff development, internal business processes, formed a model of a balanced scorecard of safety-oriented management in the corporate security of construction companies with identification of sources of information (fig. 3). Within each area of a balanced scorecard of safety-oriented management, it is important to follow the mandatory stages, such as setting goals, collecting information, evaluating and streamlining, analyzing information, forming instructions on the procedure, approving the form of reports, uniform in format for all areas of activity in order to communicate to management and simplify their understanding and make further decisions for management.

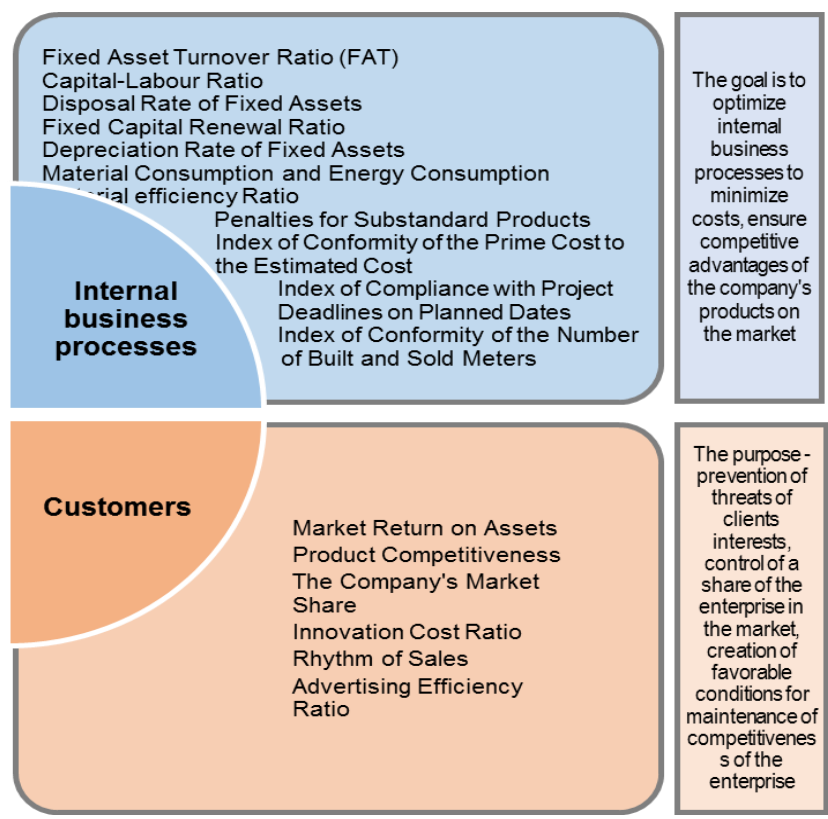

Fig. 3. Model of a balanced scorecard of safety-oriented management in the system of corporate security of construction companies

The success of solving a specific problem of further analysis depends on how well the primary information will be collected. It is important to identify a number of requirements that should be followed in determining the amount of information, namely: minimality, sufficiency and comprehensiveness. Excess information overloads the information array and leads to unjustified costs for its processing. Lack of information leads to a superficial, shallow assessment of factors. Lack of comprehensiveness leads to limited conclusions. The information collected must also be reliable, consistent and useful to achieve a specific goal. This stage of the process of developing a balanced scorecard is critical to the operation of the entire system, as it minimizes non-productive time and money. The effectiveness of each management area largely depends on information support. The quality of information used for management decisions largely depends on the amount of financial resources, level of profitability, market value of the enterprise, alternative choices of investment projects and available financial instruments and other indicators that characterize the level of well-being of owners and staff, the pace of enterprise development.

The information management system of the company's management is a continuous and purposeful selection of relevant information indicators that are 
necessary for the analysis, planning and preparation of effective management decisions in the field of safetyoriented management in all areas of the enterprise. At this stage, it is important to clearly define the timing of information collection. It is not allowed to collect information prematurely, when the conditions for revealing the fact or change of circumstances have not yet appeared, or to receive it late. Of great importance for the proper collection of information is the knowledge of the sources from which the information needed for analysis can be obtained. The range of sources of information largely depends on the purpose of the study, the direction of the analysis, the department in whose interests it was carried out. The information is selected from all available sources, but taking into account the specifics, so as not to expand the range of sources to infinity. On certain issues, the collection of information may be carried out in secret using the intelligence capabilities of the security service of the enterprise.

The information system of safety-oriented management should provide the necessary information not only to the management staff and owners of the enterprise, but also to satisfy the interests of a wide range of external stakeholders. At this stage, for each of the identified areas, a list of scores is developed, which should be calculated within its limits, which should be set benchmarks as normative values, the procedure for analyzing deviations of actual values from normative, development of measures to improve indicators to increase safety. enterprises. It is also important to divide the structural departments of the enterprise, relating to each of these areas. For each department it is necessary to establish for calculation and estimation, achievement of result of which indicators it corresponds, how it is motivated to watch and provide their standard level for the given enterprise.

According to research, the purpose of the financial sector of the enterprise is to optimize financial costs, strengthen financial stability, increase solvency, increase profitability. To ensure the achievement of the goal of this area, the following indicators are defined: absolute, fast and total liquidity ratio, financial independence ratio, financial risk, maneuverability ratio of own current assets, turnover of all enterprise capital, turnover of enterprise assets, turnover of receivables and payables, ratio, equity, products, sales. To work on indicators in this area can be attributed to such structural departments of the enterprise as accounting, economics and finance. The analysis of financial indicators is usually based on retrospective data, but it is possible to assess the results of the enterprise, determine the effectiveness of activities and redistribution of internal resources of the company to increase financial results, increase value and business security. The information base of this area is primarily financial statements, data from the company's accounting registers, data from statistical sites, internal management reporting of the company.

The purpose of the structures responsible for the field of training and development of staff is to prevent and prevent negative events due to the actions of staff, protect the interests of staff, create favorable working conditions. To ensure the achievement of the goal in this area, the following list of indicators is defined: staffing ratio, staff turnover, age structure of staff, staff stability, labor productivity, labor discipline ratio, wage motivation, educational level and intellectual level of employees. To work on indicators in this area can be attributed to such structural departments of the enterprise as the department of selection and hiring of personnel. This area of activity should provide not only the calculation and analysis of the above indicators, but also cover the processes of staff training, creating a system of work motivation, creating standards for the characterization of work not only production but also administrative staff. The information base of this area is the data of accounting and personnel registers of the enterprise, data of statistical sites, internal tables on personnel information, identity cards of employees. It is also important to note that there is a direct relationship between such indicators of the company as the quality of internal service, employee satisfaction, employee retention, quality of external service, customer satisfaction, customer retention, profit. Staff satisfaction affects the quality of services provided; satisfied staff is more loyal to the company and makes a greater contribution to its development; a satisfied employee is unlikely to resign. In order for employees to take care of their customers, management needs to create comfortable working conditions. Thus, the field of staff training and development is directly related to the field of clients.

The purpose of the client's structures is to prevent threats to the interests of customers, control the company's market share, create favorable conditions to ensure the competitiveness of the enterprise. This structure should assess the risks both inside the company and outside. In this area, the creation of the information base is mostly "experienced", i.e. by means of surveying competitors directly on the spot. To analyze the external factors influencing the consumer of the enterprise, it is recommended to use the method of "mystery shopper", which allows you to get information about how a competitor builds a policy of interaction with customers (communication by phone and in person). Analysis of pricing policies and methods of sales promotion can be done by analyzing the price lists of competitors and information posted on websites and in the media. Analysis of advertising activity requires tracking of sources of information in which information about competing firms can be placed, in particular sites http://www.novostroy.info; http://stroyobzor.ua/kharkov; http://proconsul.com.ua. Knowing the means of advertising and the cost of ad units, you can calculate the advertising budgets of competitors. An important way to obtain information is to conduct a survey of buyers, in order to identify problem areas in the company's projects, the attitude of buyers to the quality of products, identify its shortcomings. The indicators of this area include the coefficient of market return on assets, product competitiveness, market share, the coefficient of innovation costs, the rhythm of sales, the coefficient of advertising efficiency. In this area, the priority areas of the enterprise are also determined, taking into account the interests of consumers in accordance with the prices at which they are willing to purchase the company's 
products. It is also important to study the image of the competitor in the market, the number of consumers, the breadth of the product range, the level of competitiveness of the main groups of goods, the level of prices for goods and the quality of the communication system, the level of customer service. Marketing and sales departments can be assigned to work on indicators of this area. It was established that this area is aimed at achieving the following goals: to focus on the market needs of consumers, to timely fulfill contractual obligations to them, to improve the quality of products, current and after sales service, to ensure a high rate of expansion of the enterprise, to fully use the property, financial, personnel and other resources of the company, to ensure flexibility of operations in accordance with constantly changing conditions.

The sphere of internal business processes is the most unique for each enterprise, as it depends on the ways of organization and specifics of the enterprise, the class of consumers on which the company is focused. The generalized indicators of this area include: return on fixed assets, capital adequacy, the rate of disposal of fixed assets, the rate of renewal of fixed capital, depreciation of fixed assets, material consumption, energy consumption, efficiency of materials, fines for substandard products. The paper also proposes the use in this area of the index of conformity of the cost to the estimated cost, the index of compliance with the project deadlines to the planned dates, the index of conformity of the number of built and sold meters. The sphere of internal business processes covers the activities of more divisions of the enterprise than the previous ones, in particular it can include the production department, budget department, labor protection department, economic and financial department, legal department, technical construction supervision department. The information base, for the most part, is the internal reporting of each unit, the centers of responsibility for each individual project and the enterprise as a whole.

The next step in creating a balanced scorecard of safety-oriented management is to evaluate and stimulate the work of the workers involved in its implementation. To do this, each employee must write a job description, not formally, but with a detailed description of tasks, competencies, functions, powers and responsibilities; consider existing methods of evaluation and incentives, compare them; try to sample existing methodologies for each position; analyze the results and accept or reject the tested options.

For the successful implementation of the proposed model of safety-oriented management in the corporate security system of construction companies, it is advisable to use different methods of assessing the effectiveness of a balanced scorecard, in particular: assessment by coefficients (coefficients are developed directly at each enterprise ); expert assessment The essence of the method is that the company allocates a group of specialists (usually TOP managers), in one way or another related to the work of units involved in creating a balanced scorecard. They become experts who evaluate the work of the relevant unit. At the end of the reporting period, each of the experts evaluates the work of the unit on a certain conditional scale. After that there is an average indicator which is an estimation of work of division for such period and depending on it make decisions on a level of competence, efficiency, and accordingly awarding).

When developing and implementing a balanced safety-oriented management system, it is important to ensure that each area of business understands not only its own functions, goals and objectives, but also the functions of other areas to quickly delegate and receive feedback as needed.

\section{Conclusions}

Thus, according to the study, safety-oriented management is defined as a type of management activity, a set of coordinated actions, activities and processes aimed at achieving the optimal level of corporate security in enterprise development, the key task of which is to balance corporate security and enterprise development. , which determines the formation of a balanced system of information and analytical support for safety-oriented management, taking into account the interests of all groups of stakeholders.

The sequence has been established for procedures in the system of security-oriented management, including risk assessment, development and implementation of security policy, definition of requirements, control and monitoring of external and internal environment and the feasibility of information-analytical support of securityoriented management with a balanced system model. indicators.

The introduction of a model of a balanced scorecard of safety-oriented management of construction companies allows to systematically present the overall strategy of the company with specification of tasks for each unit, using specific qualitative and quantitative indicators, which promotes consistency from the lowest levels of production (construction worker) to TOP managers, and accordingly, allows to increase the efficiency of internal business processes, personnel qualification, and as a result ensure maximization of profit, preservation of interests of employees and customers, safe implementation of business projects.

\section{References}

1. "Development of the Construction Industry and De-shadowing of the Labor Market in Construction", available at : https://www.minregion.gov.ua/press/ news / rozvitok-budivelnoyi-galuzi-ta-detinizatsiya-rinku-pratsi-u-budivnitstvi (last accesses 21.05.2021)

2. "Road Clearance: Due to Which Construction Developed in 2020", available at: https://gmk.center/en/posts/dorozhnij-prosvit-zarahunok-chogo-rozvivalosya-budivnictvo-u-2020-roci/ (last accesses 21.05.2021)

3. "The State of Business Activity of Construction https://ukrstat.org/en/operativ/operativ2021/fin/rp/bud/bud_I\%D0\%86kv_2021_u.pdf (last accesses 15.05.2021) 
4. Zachko, O. B. (2015), "Methodological Basis of Security-oriented Management of Projects for the Development of Complex Systems", Management of complex systems development, No. 23 (1), P. 51-55.

5. Rudnichenko, Ye. M., Havlovska, N. I., Yadukha, S. Y. (2018), "Implementation of Managerial Innovations in the System of Providing Economic Security for Subjects of Foreign Economic Activity", Scientific Bulletin of Polissya, No. 1 (13), Ch. 1, P. 88-94.

6. Voloshchuk, L. O. (2016), Theoretical and Methodological Principles of Safety-oriented Management of Innovative Development of an Industrial Enterprise : dis. ... Dr. of Science in Economics: special. 08.00.04 - Economics and management. of enterprises, Odessa nat Polytechnic un-t, $605 \mathrm{p}$.

7. Bashinskaya, I. O. (2019), "The Mechanism of Ensuring Safety-oriented Management of an Industrial Enterprise", Problems of System Approach in Economics: Book of Proceedings, No. 6 (74), P. 21-26.

8. Ptashchenko, L. O. (2019), "Anti-raider Security-oriented Enterprise Management", Economic Security: State, Region, Enterprise: Monograph in 3 vol. / for the general. ed. V. O. Onishchenko and G. V. Kozachenko, Poltava : PoltNTU, Vol. 3, P. $229-247$.

9. Prokopenko, O., Omelyanenko, V. (2020), "Security-oriented Change Management in the Business Processes of an Industrial Enterprise", International Scientific Journal "Internauka". Series: "Economic Sciences", No. 4. DOI: https://doi.org/10.25313/2520-2294-2020-45927

10. Gavlovskaya, N. I. (2016), "A Security-Oriented Environment for the Operation of Enterprises-subjects of Foreign Economic Activity", Economy and Region, No. 3, P. 80-85.

11. Gavlovskaya, N. I. (2016), Economic Security of Foreign Economic Activity of Industrial Enterprises: Evaluation, Modeling, Support Mechanism : Monograph, Khmelnytsky : FOP Melnyk A. A., 480 p.

12. Zachko, O. B. (2015), Methodology of Security-oriented Project Management of Complex Systems (on the example of civil protection) : dis. ... Dr. Tech. Science: 05.13.22. Lviv State University of Life Safety, Lviv, 342 p.

13. Rudnichenko, Ye., Krymchak, L., Franchuk, V., Havlovska, N., Melnyk, S. (2020), "Justification Of Management Decisions On Assessing The State Of Economic Security Based On Financial Indicators", International Journal of Scientific \& Technology Research, Vol. 9 (7), P. 44-49.

14. Otenko I.P., Komarkov, D. V., Shkreben, R. P. (2018), "Strategic Tools of Security-oriented Enterprise Development", Problems of Economy, No. 2, P. 235-241.

15. Pritis, V. I. (2020), "Conditions for the Implementation of Security-oriented Management of Enterprises, Taking into Account Existing Threats", Business Inform, No. 3, P. 453-459.

Received 13.05.2021

Відомості про авторів / Сведения об авторах / About the Authors

Момот Тетяна Валеріївна - доктор економічних наук, професор, Харківський національний університет міського господарства імені О. М. Бекетова, завідувач кафедри фінансово-економічної безпеки, обліку і аудиту, Харків, Україна email: tvmomot@gmail.com; ORCID: https://orcid.org/0000-0001-7397-3565.

Момот Татьяна Валерьевна - доктор экономических наук, профессор, Харьковский национальный университет городского хозяйства имени А. Н. Бекетова, заведующая кафедры финансово-экономической безопасности, учета и аудита, Харьков, Украина.

Momot Tetiana - Doctor of Sciences (Economics), O. M. Beketov National University of Urban Economy in Kharkiv, Head of the Department of Financial and Economic Security, Accounting and Auditing, Kharkiv, Ukraine.

Філонич Олена Миколаївна - кандидат економічних наук, доцент, Харківський національний університет міського господарства імені О. М. Бекетова, докторант кафедри фінансово-економічної безпеки, обліку і аудиту, м. Харків, Україна; email: lenyciaglbuh@gmail.com; ORCID: https://orcid.org/0000-0001-5428-6794.

Филонич Елена Николаевна - кандидат экономических наук, доцент, Харьковский национальный университет городского хозяйства имени А. Н. Бекетова, докторант кафедры финансово-экономической безопасности, учета и аудита, Харьков, Украина

Filonych Olena - PhD (Economics Sciences), O. M. Beketov National University of Urban Economy in Kharkiv, Doctoral Student of the Department of Financial and Economic Security, Accounting and Auditing, Kharkiv, Ukraine.

Косяк Антоніна Петрівна - кандидат економічних наук, доцент, Харківський національний університет міського господарства імені О. М. Бекетова, доцент кафедри фінансово-економічної безпеки, обліку і аудиту, Харків, Україна; етаіl: zітаant@ukr.net; ORCID: https://orcid.org/0000-0003-1009-4082.

Косяк Антонина Петровна - кандидат экономических наук, доцент, Харьковский национальный университет городского хозяйства имени А. Н. Бекетова, доцент кафедры финансово-экономической безопасности, учета и аудита, Харьков, Украина.

Kosiak Antonina - PhD (Economics Sciences), O. M. Beketov National University of Urban Economy in Kharkiv, Associate Professor of the Department of Financial and Economic Security, Accounting and Auditing, Kharkiv, Ukraine.

Лобач Олена Володимирівна - кандидат технічних наук, доцент, Національний технічний університет "Харківський політехнічний інститут", доцент кафедри стратегічного управління, Харків, Україна; еmail: e.v.lobach@gmail.com, ORCID: https://orcid.org/0000-0001-7494-9997.

Лобач Елена Владимировна - кандидат технических наук, доцент, Национальный технический университет "Харьковский политехнический институт", доцент кафедры стратегического управления, Харьков, Украина.

Lobach Olena - PhD (Engineering Sciences), Associate Professor, National Technical University "Kharkiv Polytechnic Institute", Associate Professor of the Department of Strategic Management, Kharkiv, Ukraine.

\section{ЗБАЛАНСОВАНА СИСТЕМА ПОКАЗНИКІВ ЗАБЕЗПЕЧЕННЯ БЕЗПЕКООРІЕНТОВАНОГО УПРАВЛІННЯ ПІДПРИЄМСТВ БУДІВЕЛЬНОӤ ГАЛУЗІ}

Стаття присвячена дослідженню теоретико-методичних засад розробки збалансованої системи показників забезпечення безпекоорієнтованого управління підприємств будівельної галузі. Предметом дослідження $є$ сукупність теоретичних, методичних і практичних аспектів щодо забезпечення формування розробки збалансованої системи показників забезпечення безпекоорієнтованого управління підприємств будівельної галузі. Метою статті є розробка теоретико-методичних положень 
та обгрунтування практичних рекомендацій щодо формування моделі збалансованої системи показників забезпечення безпекоорієнтованого управління підприємств будівельної галузі із врахуванням інтересів усіх груп стейкхолдерів. Завдання роботи: проаналізувати сучасні тенденції розвитку підприємств будівельної галузі України; узагальнити підходи до визначення поняття безпекоорієнтованого управління; дослідити та систематизувати елементи безпекоорієнтованого управління; розробити модель збалансованої системи показників забезпечення безпекоорієнтованого управління в системі корпоративної безпеки підприємств будівельної галузі. У ході дослідження використано методи: абстрактно-логічний аналіз, теоретичного узагальнення та систематизації, системний аналіз. В роботі проаналізовано динаміку розвитку підприємств будівельної галузі України в умовах запровадження карантинних заходів, пов'язаних з COVID-19. Bстановлено фактори, що стримують будівельну діяльність, до яких віднесено фінансові обмеження, недостатній попит, нестача робочої сили, погодні умови. Узагальнено підходи до визначення безпекоорієнтованого управління та удосконалено визначення безпекоорієнтованого управління в системі корпоративної безпеки. Систематизовано елементи безпекоорієнтованого управління із конкретизацією таких складових як оцінка ризиків, розробка та впровадження політики безпеки, визначення вимог, встановлення контролю та моніторинг зовнішнього та внутрішнього середовища. Розроблено модель збалансованої системи показників забезпечення безпекоорієнтованого управління підприємств будівельної галузі. Висновки. В процесі дослідження обгрунтовано доцільність формування збалансованої системи показників забезпечення безпекоорієнтованого управління підприємств будівельної галузі із врахуванням динаміки виконання будівельних робіт протягом $2019-2021$ рр. Детально представлені елементи системи безпекоорієнтованого управління та обгрунтовано доцільність формування збалансованої системи показників забезпечення безпекоорієнтованого управління підприємств будівельної галузі. Деталізовано послідовність формування збалансованої системи показників забезпечення безпекоорієнтованого управління із конкретизацією системи показників для оцінки стратегічних цілей за складовими збалансованої системи показників: фінанси, клієнти, внутрішні бізнес-процесів, навчання та розвиток.

Ключові слова: безпекоорієнтоване управління, корпоративна безпека, збалансована система показників, підприємства будівельної галузі.

\section{СБАЛАНСИРОВАННАЯ СИСТЕМА ПОКАЗАТЕЛЕЙ ОБЕСПЕЧЕНИЯ БЕЗОПАСНО-ОРИЕНТИРОВАННОГО УПРАВЛЕНИЯ ПРЕДПРИЯТИЙ СТРОИТЕЛЬНОЙ ОТРАСЛИ}

Статья посвящена исследованию теоретико-методических основ разработки сбалансированной системы показателей обеспечения безопасно-ориентированного управления предприятий строительной отрасли. Предметом исследования является совокупность теоретических, методических и практических аспектов по обеспечению формирования разработки сбалансированной системы показателей обеспечения безопасно-ориентированного управления предприятий строительной отрасли. Целью статьи является разработка теоретико-методических положений и обоснование практических рекомендаций по формированию модели сбалансированной системы показателей обеспечения безопасно-ориентированного управления предприятий строительной отрасли с учетом интересов всех групп стейкхолдеров. Задачи работы: проанализировать современные тенденции развития предприятий строительной отрасли Украины; обобщить подходы к определению понятия безопасно-ориентированного управления; исследовать и систематизировать элементы безопасно-ориентированного управления; разработать модель сбалансированной системы показателей обеспечения безопасно-ориентированного управления в системе корпоративной безопасности предприятий строительной отрасли. В ходе исследования использованы методы: абстрактно-логический анализ, теоретического обобщения и систематизации, системный анализ. В работе проанализирована динамика развития предприятий строительной отрасли Украины в условиях введения карантинных мероприятий, связанных с COVID-19. Установлены факторы, сдерживающие строительную деятельность, к которым отнесены финансовые ограничения, недостаточный спрос, нехватка рабочей силы, погодные условия. Обобщены подходы к определению безопасно-ориентированного управления и усовершенствована определения безопасно-ориентированного управления в системе корпоративной безопасности. Систематизированы элементы безопасно-ориентированного управления с конкретизацией таких составляющих как оценка рисков, разработка и внедрение политики безопасности, определения требований, установления контроля и мониторинг внешней и внутренней среды. Разработана модель сбалансированной системы показателей обеспечения безопасно-ориентированного управления предприятий строительной отрасли. Выводы. В процессе исследования обоснована целесообразность формирования сбалансированной системы показателей обеспечения безопасно-ориентированного управления предприятий строительной отрасли с учетом динамики выполнения строительных работ в течение 2019-2021 гг. Подробно представлены элементы системы безопасно-ориентированного управления и обоснована целесообразность формирования сбалансированной системы показателей обеспечения безопасноориентированного управления предприятий строительной отрасли. Детализировано последовательность формирования сбалансированной системы показателей обеспечения безопасно-ориентированного управления с конкретизацией системы показателей для оценки стратегических целей по составляющим сбалансированной системы показателей: финансы, клиенты, внутренние бизнес-процессов, обучение и развитие.

Ключевые слова: безопасно-ориентированное управление, корпоративная безопасность, сбалансированная система показателей, предприятия строительной отрасли.

Бібліографічні описи / Bibliographic descriptions

Момот Т. В., Філонич О. М., Косяк А. П., Лобач О. В. Збалансована система показників забезпечення безпекоорієнтованого управління підприємств будівельної галузі. Сучасний стан наукових досліджень та технологій в промисловості. 2021. № 2 (16). C. 54-62. DOI: https://doi.org/10.30837/ITSSI.2021.16.054

Momot, T., Filonych, O., Kosiak, A., Lobach, O. (2021), "Balanced scorecard of safety-oriented management for the construction industry enterprises", Innovative Technologies and Scientific Solutions for Industries, No. 2 (16), P.54-62. DOI: https://doi.org/10.30837/ITSSI.2021.16.054 